\title{
SOWING DATES AND MOLYBDENUM FOLIAR APPLICATION FOR TWO PEANUT CULTIVARS
}

\author{
Sérgio Iraide Bernardes Soares Filho ${ }^{1}$, Edson Lazarini², Valdeci Orioli Júnior ${ }^{3^{*}}$, João Victor Silva Bernardes ${ }^{4}$
}

\author{
1'Mestre em Agricultura, Faculdade de Ciências Agronômicas, Universidade Estadual Paulista (UNESP), Fazenda Lageado, Av. \\ Universitária, 3780 - Altos do Paraíso, Botucatu/SP - CEP: 18.610-034 \\ 2Docente, Departamento de Fitotecnia, Tecnologia de Alimentos e Sócio-Economia, Faculdade de Engenharia, Universidade Estadual \\ Paulista (UNESP), R. Monção, 226 - Zona Norte, Ilha Solteira/SP - CEP 15.385-000 \\ ${ }^{3}$ Docente, Instituto Federal de Educação, Ciência e Tecnologia do Triângulo Mineiro (IFTM), Campus Uberaba, R. João Batista Ribeiro, \\ 4000 - Distrito Industrial II, Uberaba/MG - CEP 38.064-790 \\ ${ }^{4}$ Discente do Curso de Engenharia Agronômica, Instituto Federal de Educação, Ciência e Tecnologia do Triângulo Mineiro (IFTM), \\ Campus Uberaba, R. João Batista Ribeiro, 4000 - Distrito Industrial II, Uberaba/MG - CEP 38.064-790
}

Autor para correspondência: Valdeci Orioli Júnior, valdeci@iftm.edu.br

\begin{abstract}
The study aimed to assess application efficiency of Mo doses through leaves in two sowing dates and different phenological stages on agronomic characteristics of two peanut cultivars. The experimental design was a randomized block with four replications, with the treatments arranged in a factorial design $2 \times 2 \times 6 \times 2$, being two cultivars (IAC Tatu and IAC 886), two sowing dates, six Mo doses applied to the leaves (0, 50, 100, 200, 400 and $800 \mathrm{~g} \mathrm{ha}^{-1}$ ) and two application times (early flowering and early seed formation). Were evaluated the number of pods/plant, the number of grains/pod, the weight of 100 grains, the yield of grain, the pod production and protein, lipids and the Mo contents in the grains. The highest pod yields were obtained with sowing in November, for both cultivars. The IAC 886 presents a significantly higher production than IAC Tatu when sown in November. When the seeds were sown in March, the cultivars showed similar productions. Foliar application of Mo at flowering and pod formation did not affect the agronomic characteristics, protein and lipid contents in peanut grains. The increase in Mo doses increased the content of this micronutrient in the grains.
\end{abstract}

KEYWORDS: Arachis hypogaea L.; IAC 886; IAC Tatu; molybdenum fertilization.

\section{ÉPOCAS DE SEMEADURA E APLICAÇÃO FOLIAR DE MOLIBDÊNIO PARA DOIS CULTIVARES DE AMENDOIM}

RESUMO: O trabalho teve como objetivo avaliar a eficácia da aplicação de diferentes doses de Mo em duas épocas de semeadura e estádios fenológicos de dois cultivares de amendoim. 0 delineamento experimental utilizado foi em blocos casualizados com quatro repetições, com os tratamentos dispostos em um esquema fatorial $2 \times 2 \times 6 \times 2$, sendo, duas variedades (IAC Tatu e IAC 886), duas épocas de semeadura, seis doses de Mo aplicados via foliar $\left(0,50,100,200,400\right.$ e $\left.800 \mathrm{~g} \mathrm{ha}^{-1}\right)$ e duas épocas de aplicação (início do florescimento e início da formação dos grãos). Foram avaliados o número de vagens/planta, o número de grãos/vagem, a massa de 100 grãos, o rendimento em grãos, a produção de vagens e o teor de proteína, lipídeos e Mo nos grãos. As maiores produções de vagens foram obtidas com a semeadura em novembro, para ambos os cultivares. 0 cultivar IAC 886 apresenta produção significativamente superior ao IAC Tatu quando semeados em novembro. Quando a semeadura foi realizada em março, os cultivares apresentaram produções semelhantes. A aplicação foliar de Mo, no início do florescimento ou formação de vagens, não alterou as características agronômicas e os teores de proteína e lipídeos nos grãos de amendoim. 0 aumento das doses de Mo elevou o teor desse micronutriente nos grãos.

PALAVRAS-CHAVE: Arachis hypogaea L.; IAC 886; IAC Tatu; adubação molíbdica.

\section{INTRODUCTION}

The Brazilian peanut production is mainly concentrated at the North and West regions of Sao
Paulo State. At the West region, peanut has been cultivated in areas where once were pastures and sown in two times: October/November and February. At the 
Noth region, peanut has been cultivated in sugarcane renewing areas, usually during the month of November (Bolonhezi et al., 2005). These areas are composed by various soil types, including acidic soils of low fertility.

The recommended period for peanut sowing at the Sao Paulo state, however, does not take into account the climatic specificities of the different regions, indicating, widely, the months of October or November and February or March, as the most appropriate for peanut sowing during the raining and dry season, respectively (Godoy et al., 2014). Some studies on peanut sowing times have shown that highest yields are achieved when the crop is implanted at the beginning of the raining season (Peixoto et al., 2008; Kasai et al., 1999). They also shown that, even during the dry season, the postponement of the sowing time has a positive influence in the crop's production (Crusciol et al., 2000).

Even though the crops require a low amount of Mo, the peanut may have its production compromised by Mo deficiency when cultivated in acidic soils, because in this condition (low pH) there is a significant reduction of the availability of the nutrient to the plants. Mo is essential for the reduction of nitrate and $\mathrm{N}$ can be absorbed by the plants, since it is part of the reductase enzyme. In legumes, such as peanut, this element has also played an important role in the fixation of the atmospheric $\mathrm{N}$ by the rhizobium, once it is a component of the nitrogenase enzyme complex (Malavolta et al., 1997). Although, its application has been recommended for some crops, for peanut the research results have been controversial. Zheng et al. (2011), in China, and Cruciol et al. (2019), verified an increase in productivity with the application of Mo. However, Caires e Rosolem (1995) and Silva et al. (2009) did not observe positive effects in pod productivity and peanut grains with the application of molybdenum fertilization in production components.

The supply of Mo can be delivered by seed coating, foliar application or soil application. This last modality of application has not been successful, because this nutrient is able to react with the mineral constituents and organics of the soil, becoming unavailable to the plants. The application via seeds is possible, since a low rate of Mo is applied and has been usually recommended by the fact that this practice is more economic. Nevertheless, according to Albino and Campo (2001), the application of Mo to the seed with inoculant should be avoided once it can reduce the number of Bradyrhizobium cells, nodulation and the $\mathrm{N}$ biological fixation efficiency.

When adopting foliar fertilization not only the dose to be applied is important, but also the time in which the application is performed. However, few are the studies about molybdenum fertilization in the peanut crop, and even less are concerned about foliar fertilization.

Therefore, the objective of this study was to evaluate how Mo foliar application in two different sowing times, rates and phonologic stadium of the crop, affects the agronomic characteristics of two peanut cultivars.

\section{MATERIAL AND METHODS}

The experiment was performed at Selvíria, Mato Grosso do Sul, Brazil (2022' S, 5122' W, 335 m asl). The soil from this location is a Typic Acrustox (USDA SOIL TAXONOMY, 2014). Climate from the region is a typical AW, defined as humid tropical with rainy season during summer and dry during winter, according to the Köeppen classification, presenting temperature, precipitation and moisture annual average of $24,5^{\circ} \mathrm{C}$, $1370 \mathrm{~mm}$ e 64,8\%, respectively.

Prior to experiment installation, a chemical analysis of the soil was performed in the layer of 0-0.2 $\mathrm{m}$ depth, following the methodology described be Raij et al. (2001), and this presented the following values: $28 \mathrm{mg} \mathrm{dm}^{-3}$ de $\mathrm{P}_{(\text {resin) }} ; 15 \mathrm{~g} \mathrm{dm}^{-3}$ de OM; $\mathrm{pH}\left(\mathrm{CaCl}_{2}\right) 4.9$;

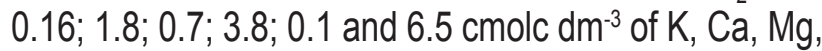
$\mathrm{H}+\mathrm{Al}$, Al e CTC, respectively, and $\mathrm{V}=42 \%$.

Soil preparation was performed conventionally, preceding each sowing. The sowing was executed manually and fertilization utilized in the seeding furrow was $150 \mathrm{~kg} \mathrm{ha}^{-1}$ of 08-28-16, based on the recommendation of Quaggio and Godoy (1997).

The experimental design utilized was in casualized blocks with four replicates, where treatments were disposed in a factorial scheme $2 \times 2 \times 6 \times 2$, being two varieties, two sowing times, six Mo doses and two application times. The plots were constituting of four rows of $5 \mathrm{~m}$ long. Considered as useful area the two central rows with $3 \mathrm{~m}$ long. For both varieties, it was utilized a space row of $0.9 \mathrm{~m}$.

The Mo doses were 0, 50, 100, 200, 400 and $800 \mathrm{~g} \mathrm{ha}^{-1}$, applied by foliar pulverization, having as 
source a product that presented $15 \%$ of Mo and density of $1.32 \mathrm{~g} \mathrm{~cm}^{-3}$. The application was executed with the assistance of a backpack sprayer, calibrated to applied $200 \mathrm{~L}$ ha-1. Pulverization was realized at the beginning of blooming (seven days after the start of blooming) and at the beginning of the grain formation (when the first formed pods-initiated grain formation).

The cultural practices were carried out according to the standard recommendation for the crop, and during the second growing season (sowing in March) it was adopted supplemental irrigation by center pivot.

At harvest time, five plants were collected inside the useful area of each plot and performed the following evaluation: number of pods per plant, number of grains per pod, weight of 1000 grains (originated from two samples of 100 grains), grain yield (relation between weight of pods and grains obtained from the sampled plants).

The plants lasting in each plot were harvested in order to estimate pod production. At this point it was also realized grain sampling to determine the protein, lipid e Mo content in the grains. The protein content was determined according to Malavolta et al. (1997) multiplying the $\mathrm{N}$ content by the factor 6.25 (A.O.A.C.,
1970). The lipid content was determined in the same sampl by extracting with hot organic solvents (hexane), utilizing the extractor soxhlet during eight hours, as recommended by A.O.C.S. (1972). The concentration of Mo was determined also in the same sample according to Malavolta et al. (1997).

The data were submitted to a variance analysis by the $F$ test $(\alpha=0.05)$, adopting the comparison of means by Tukey test ( $\alpha=0.05$ ) by sowing time effect, cultivars and Mo application time and analysis of regression for the Mo rate effect.

\section{RESULTS AND DISCUSSION}

It was observed that during the first growing season (sowing in November) the daily average temperature was, mainly, between $25-30$ oC (Figure 1). At this time precipitation was well distributed until blooming of the cultivar IAC 886 and beginning of grain filling stage of cultivar IAC Tatu. Posteriorly, rainfall occurrence was rare. At the second growing season (sowing in March), the crop was irrigated as rainfall during the whole period did not supply the crop's necessity. Also, during second crop, daily average temperature was lower than in the first growing season.

Figure 1. Rainfall, average temperature and activities performed during the experiment for first and second peanut growing season.

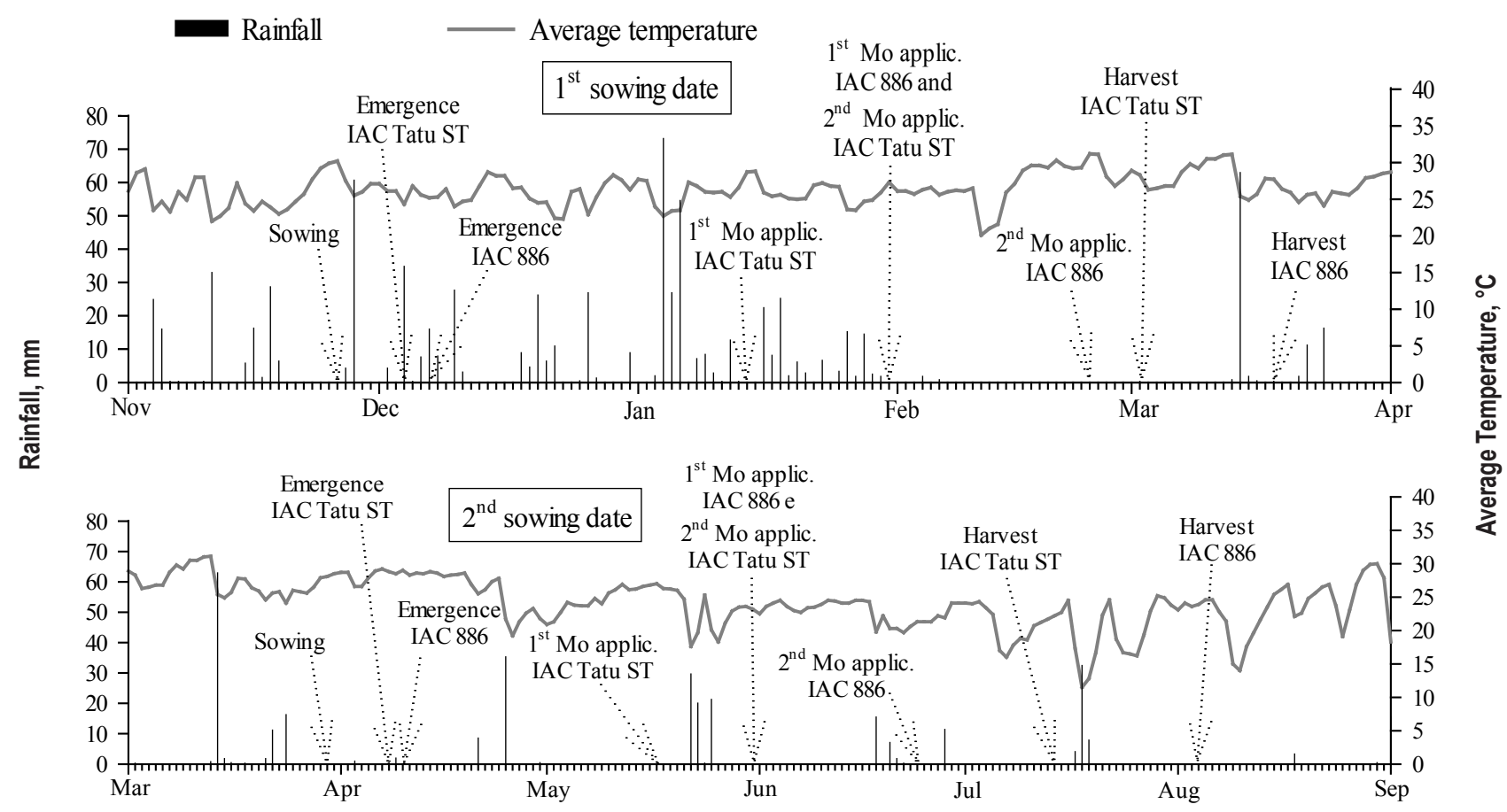


In figure 2 can be observed that both cultivars presented the highest number of pods per plant when sowed in November and, independently of the sowing time, cultivar IAC 886 produced a higher number of pods compared to IAC Tatu $\left(\mathrm{F}_{\text {(cultivar } x \text { time) }}=31.65^{\star *}\right)$. The cultivar IAC 886 possess development of grounders stems (group Virginia), and cultivar IAC Tatu possess an erect bearing (group Valencia). In fact, the cultivars belonging to group Virginia produce more gynophore and have more grounders ramifications, promoting a broader contact with gynophore-soil, reducing energetic demand and allowing a prompt development, leading to a larger viability in pod formation (Nogueira and Távora, 2005). The largest pod number observed in plants sowed in November was, probably, due to the better climatic conditions for the crop during summer (Figure 1).

Figure 2. Pods per plant, grains per pod, weight of 100 grains and pods production of two peanut cultivars (IAC 886 and IAC Tatu) sown in November and March. (lowercase letters indicate differences between cultivars within each sowing date and uppercase differences between the sowing time for each cultivar by Tukey test at $5 \%$ ).
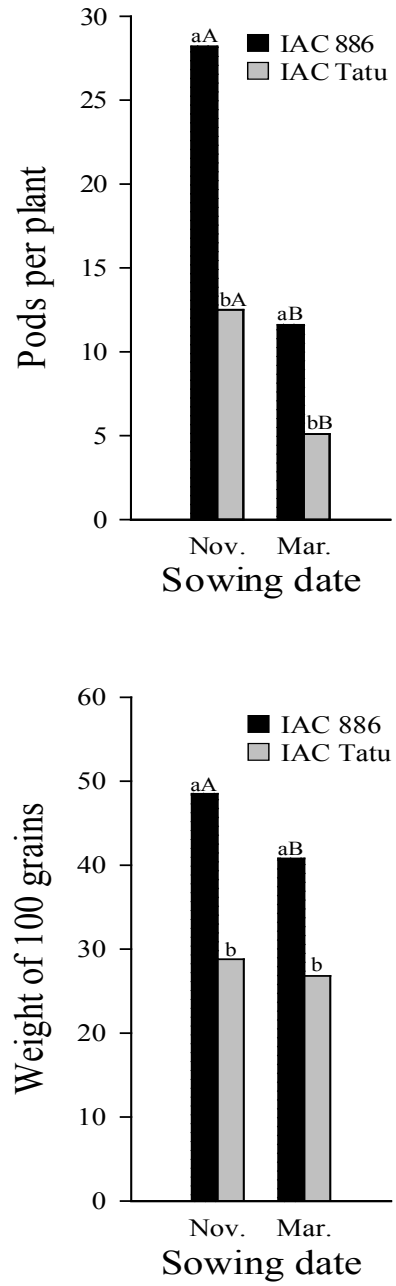

It was also observed, that the cultivar IAC Tatu presented pods with a higher grain number than IAC 886 at the November sowing date (Figure 2). However, when sowed in March, both cultivars presented similar number of grains per pod $\left(\mathrm{F}_{\text {(cultivar } x \text { time) }}=29.85^{\star *}\right)$. This variable is mainly conditioned by genetic characteristics and the larger number of grains per pod is typical of the Valencia group. Nonetheless, the lower number of grains per pod of IAC Tatu when sowed in March, is probably related to unfavorable climatic conditions that can lead to grain abortion (Smith, 1956).
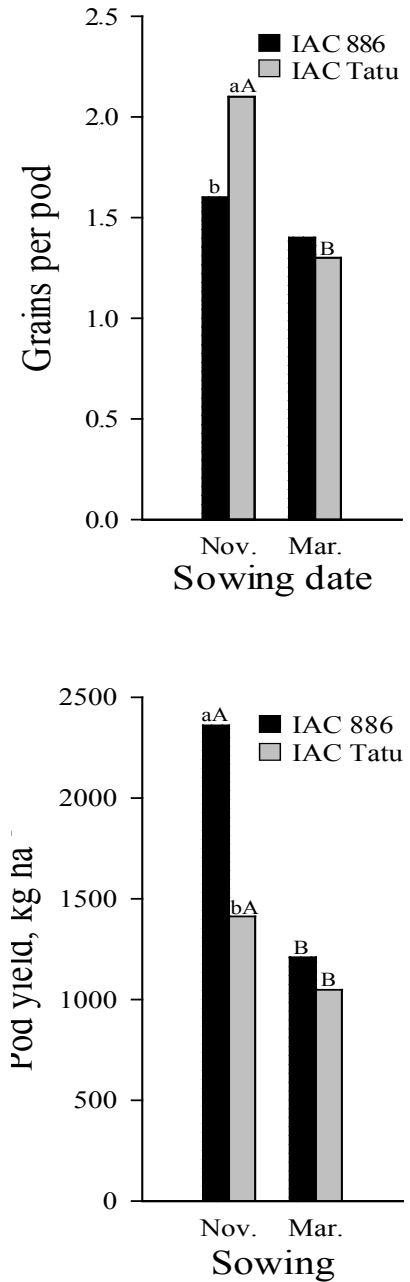

The cultivar IAC 886 presented higher grain yield than IAC Tatu in November's sowing, as well as in March's sowing $\left(\mathrm{F}_{\text {(cultivar } x \text { time) }}=8.91^{*}\right)$. November sowing for IAC 886 promoted heavier grains compared to the March sowing. The same did not occur with the cultivar IAC Tatu, that presented similar grain yield for both seasons (Figure 2). In peanut crops, when drought period matches grain filling, the ratio grain weight per pod can be affected (RAO et al., 1985). A drought period can alter grain composition, diminishing its volume and 
mass, by reducing the intake of $\mathrm{Ca}$ and other nonmobile nutrients in phloem (Ross and Kvien, 1989) and also the flux of mobile nutrients into the grains (Conkerton et al., 1989).

Also, in Figure 2, it was noticed that pod yield was different between cultivars only for November sowing, with the cultivar IAC 886 being the most productive. However, both cultivars were more productive when sown during rainy season (November) $\left(\mathrm{F}_{\text {(cultivar x time) }}=17.59^{* *}\right)$. The decrease of productivity of cultivar IAC 886 in sowing time is worth mentioning. This cultivar presents a higher production potential but it also showed itself more susceptive to adverse conditions of cultivation.

On Figure 3 it was noticed that cultivar IAC 886 also presented higher grain yield compared to IAC Tatu $\left(F=36.10^{* *}\right)$ and that sowing in November provided a grain yield per mass of pods ratio more favorable when compared to the March sowing ( $F=$ $\left.72.87^{* *}\right)$.

Figure 3. Grain yield of two peanut cultivars (IAC 886 and IAC Tatu) sown in November and March. (Different letters indicate difference by Tukey test at $5 \%)$.

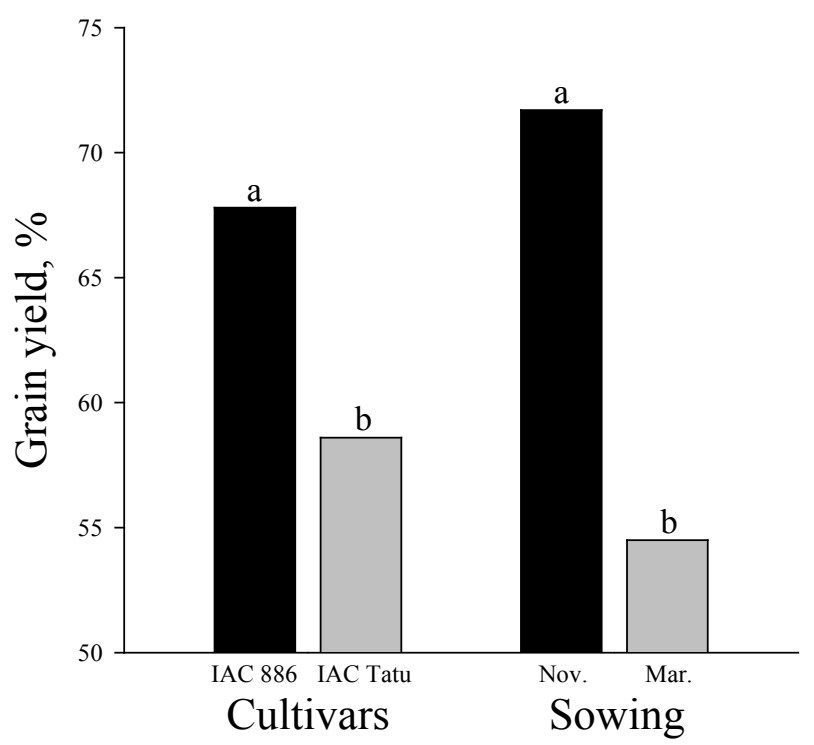

The highest number of pods per plants associated to the highest mass of 100 grains were responsible by the highest yield of pods of cultivar IAC 886 compared to the IAC Tatu, observed at the November sowing. The decrease of productivity of this cultivar when sown in March is mostly due to the reduction of the number of pods per plants. As for the cultivar IAC Tatu, the reductions of the number of pods per plants and the number of grains per pods were, both, decisive, and decay of productivity was observed between sowing time. Reductions in production components with a consequent decrease of peanut productivity and grain yield (due to the postponement of sowing time, getting closer to drier periods and less luminosity and temperature), were also observed by Peixoto et al. (2008), Crusciol et al. (2000) and Kasai et al. (1999).

In areas with low latitude such as tropical ones, the temperature does not preclude peanut cropping. According to Richardt (1987), it is possible to have a good development of the peanut, as long the average temperature is in range of 22 and $20^{\circ} \mathrm{C}$. However, even in those regions, sowing time during lower temperatures might extend the vegetative phase, postponing the floral induction and maturation (NOGUEIRA and TÁVORA, 2005), reflecting on yield. Crusciol et al. (2000) verified that, even in the dry season cultivation, late sowing causes an increase in the number of days until peanut blooming. Nakagawa et al. (1986) also observed a longer cycle for peanut crops cultivated on dry season compared to the ones cultivated in the rainy season.

Likewise, despite the length of the day not influencing blooming in peanut (GILLIER and SILVESTRE, 1970), under optimum temperature conditions the reduction of the length of the day during blooming, as in late sowing, might cause a reduction in the number of flowers. What, apparently, is related to a higher or lower production of assimilated nutrients that the plants utilize for its growth and differentiation (NOGUEIRA and TÁVORA, 2005).

Regarding the protein and lipid contents of the grains, it was observed that there was difference $\left(F_{\text {protein }}=33,11^{* *} ; F_{\text {lipid }}=109,10^{* *}\right)$ between the cultivars (Figure 4). The cultivar IAC Tatu presented the highest protein and lipid contents. According to Silva et al. (2012), the protein content of the peanut grains is variable between cultivars and also according to the growing conditions. Nevertheless, the protein and lipids contents (Figure 4) was not influenced by sowing time $\left(F_{\text {protein }}=1,23 \mathrm{NS} ; F_{\text {lipid }}=0,98 \mathrm{NS}\right)$ as well as the application time $\left(F_{\text {protein }}=1,72 \mathrm{NS} ; F_{\text {lipid }}=\right.$ $0,25 \mathrm{NS}$ ) and Mo rates (Figure 5). 
Figure 4. Protein, lipid and Mo content in peanut grains due to cultivars, sowing time and Mo application time. (Different letters indicate difference by Tukey test at $5 \%$ ).
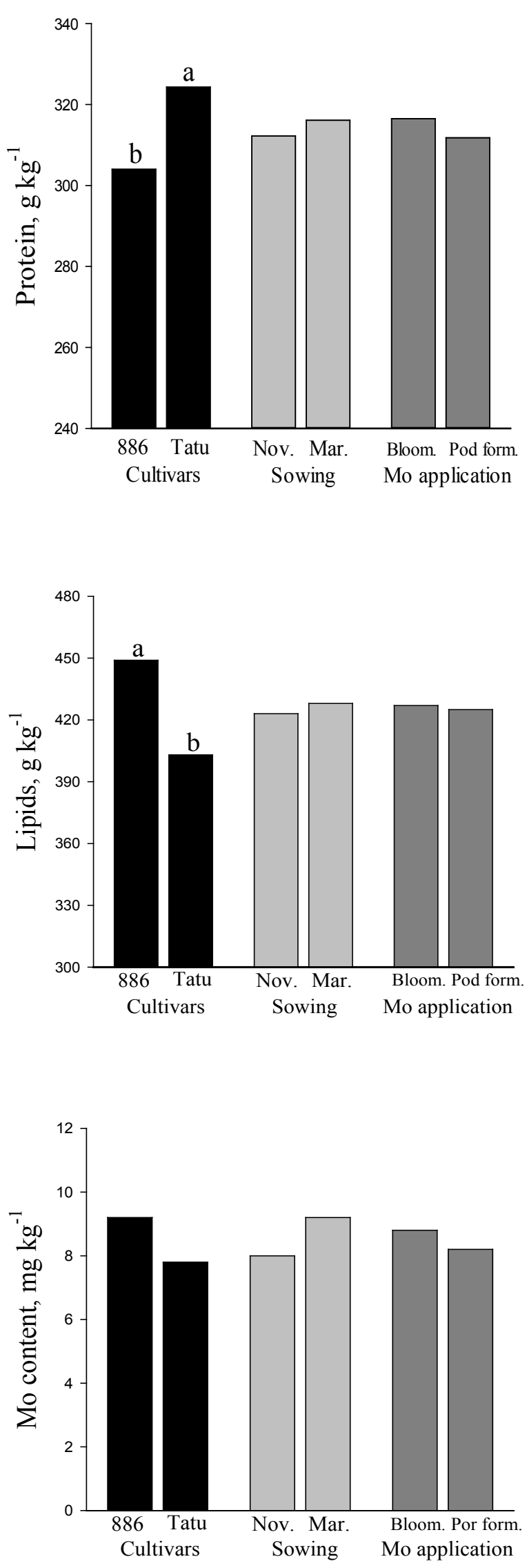

Figure 5. Molybdenum, protein and lipid content in peanut grains due to Mo rates.

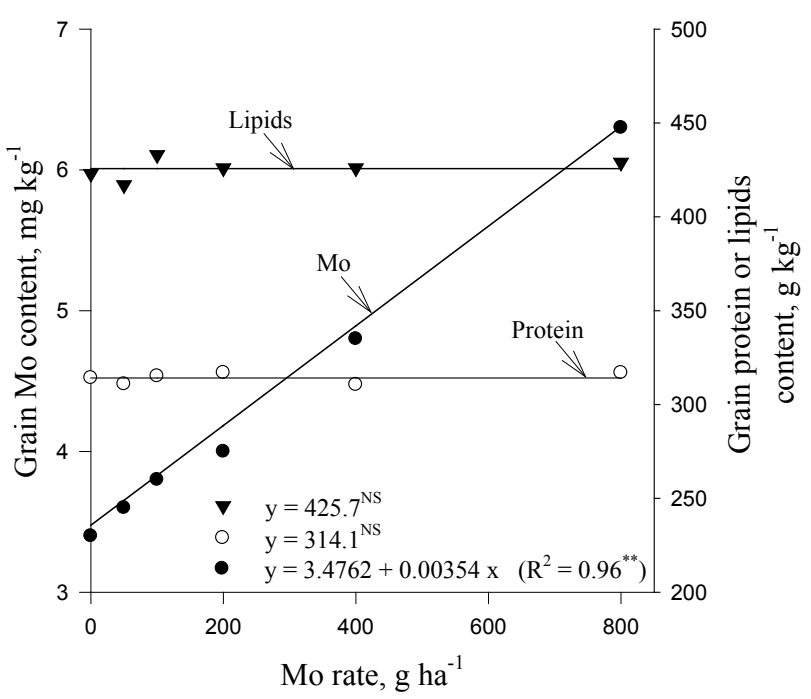

The Mo content of the grains (Figure 4) was not influenced by the cultivars ( $F=1,14 \mathrm{NS})$, by sowing time ( $F$ $=0,80 \mathrm{NS})$ and by the time of supply of the micronutrient $(\mathrm{F}=$ $0,18 \mathrm{NS})$. However, it was verified a difference for Mo rates $\left(F=8.74^{* *}\right)$ and a linear increase as rates were increased (Figure 5). Apparently, a major part of Mo absorbed by the peanut plants is destined to the grains, as observed by Du et al. (1999). As in for soybean, it is estimated that around $67 \%$ of the Mo is in the legume by the end of the crop's cycle. This result is important since the foliar application of Mo is effective in order to enrich the seeds with this nutrient and that enriched seeds are capable of providing conditions to higher yields, as observed by Campo et al. (2009) with soybean.

As for Mo application it was noticed, on Table 1 , that Mo rates as well as the time of application of this micronutrient did not influence yield components. These results disagree with the observed by Zheng et al. (2011) in China that, sowing peanut in spring and summer, verified that the foliar application of Mo contributed to increase the number of pods per plants and peanut yield sown in spring. Likewise, Crusciol et al. (2019) found that the Mo foliar application in the peanut crop (cv. IAC 886), in pre-blooming, also increased the number of pods per plant and the yield. According to these authors, the low $\mathrm{pH}$ and available Mo content $\left(0.003 \mathrm{mg} \mathrm{kg}^{-1}\right)$ of the soil, due to the use of the area for 20 consecutive years for grazing without adequate management, are the factors responsible for the positive effects of Mo application. However, by times, even though utilizing acid soils, there were no shown responses to Mo applications. In this case, the 
Mo available in the soil allied to the restrained in the this micronutrient, as observed by Caires e Rosolem seeds were sufficient to supply the crop's necessity for (1995) and Silva et al. (2009).

Table 1. Pods per plant, grains per pod, grain yield, weight of 100 grains and pod yield due to foliar Mo application.

\begin{tabular}{|c|c|c|c|c|c|}
\hline Cause of variation & $\begin{array}{c}\text { Pods per } \\
\text { plant }\end{array}$ & $\begin{array}{l}\text { Grains per } \\
\text { pod }\end{array}$ & $\begin{array}{l}\text { Grain } \\
\text { yield } \\
(\%)\end{array}$ & $\begin{array}{l}\text { Weight of } \\
100 \text { grains } \\
\text { (g) }\end{array}$ & $\begin{array}{c}\text { Pod } \\
\text { yield } \\
(\mathrm{kg} / \mathrm{ha})\end{array}$ \\
\hline \multicolumn{6}{|l|}{ Application time } \\
\hline Blooming & 14.2 & 1.6 & 63.3 & 36.2 & 1507 \\
\hline Pod formation & 14.5 & 1.6 & 62.9 & 36.5 & 1395 \\
\hline \multicolumn{6}{|l|}{ Mo rates (g ha-1) } \\
\hline 0 & 14.3 & 1.5 & 59.5 & 34.5 & 1487 \\
\hline 50 & 13.6 & 1.6 & 64.1 & 35.8 & 1484 \\
\hline 100 & 15.2 & 1.6 & 63.5 & 37.3 & 1351 \\
\hline 200 & 13.3 & 1.5 & 63.7 & 36.3 & 1424 \\
\hline 400 & 14.5 & 1.7 & 64.7 & 38.6 & 1557 \\
\hline 800 & 15.2 & 1.7 & 63.1 & 35.8 & 1402 \\
\hline \multicolumn{6}{|l|}{ F test } \\
\hline Application time & $0.20^{\mathrm{NS}}$ & $0.25^{\mathrm{NS}}$ & $0.05^{\mathrm{NS}}$ & $0.063^{\mathrm{NS}}$ & $2.21^{\mathrm{NS}}$ \\
\hline Mo rates & $0.60^{\mathrm{NS}}$ & $1.31^{\mathrm{NS}}$ & $0.99^{\mathrm{NS}}$ & $0.81^{\mathrm{NS}}$ & $0.62^{\mathrm{NS}}$ \\
\hline \multicolumn{6}{|c|}{ Regressions (Mo rates) } \\
\hline Linear & $0.74^{\mathrm{NS}}$ & $2.88^{\mathrm{NS}}$ & $0.47^{\mathrm{NS}}$ & $0.18^{\mathrm{NS}}$ & $0.02^{\mathrm{NS}}$ \\
\hline Quadratic & $0.23^{\mathrm{NS}}$ & $0.60^{\mathrm{NS}}$ & $2.13^{\mathrm{NS}}$ & $2.88^{\mathrm{NS}}$ & $0.35^{\mathrm{NS}}$ \\
\hline CV\% & 39.6 & 23.4 & 16.5 & 24.4 & 36.1 \\
\hline
\end{tabular}

NS = non-significant.

In general, it was observed in the present study that the November sowing provided higher yields for both cultivars (IAC 886 and IAC Tatu) and when sown in November, IAC 886 presented superior yield compared to IAC Tatu. However, when sown in March, both cultivars presented similar yields. Furthermore, the application of Mo, at the beginning of blooming or pod formation, did not alter the agronomic characteristics and protein and lipid content of peanut grains but there was a positive relation amongst Mo grain content and Mo rates applied via foliar.

\section{ACKNOWLEDGEMENTS}

The authors are grateful to the São Paulo Research Foundation (FAPESP) for granting a scholarship to the third author.

\section{REFERENCES}

Albino, U. B.; Campo, R. J. Efeito de fontes de doses de molibdênio na sobrevivência do Bradyrhizobium e na fixação biológica de nitrogênio em soja. Pesquisa Agropecuária Brasileira, 2001, 36, 3, 527-534.
A.O.A.C. Association of Official Agricultural Chemists. Official methods of analysis of the A.O.A.C. Washington: A.O.A.C., 1970.

A.O.C.S. American Oil Chemists Society. Official and templatizes methods of A.O.A.C. In: Smith, A. H.; Circle, S. J. (Ed.). Soybean - chemistry and technology: proteins. Wesport: Avi Publishers, 1972, 450-456.

Bolonhezi, D.; Godoy, I. J. de; Santos, R. C. dos. Manejo cultural do amendoim. In: Santos, R. C. dos (Ed.). O agronegócio do amendoim no Brasil. Campina Grande: Embrapa, 2005, 192-241.

Caires, E. F.; Rosolem, C. A. Calagem e aplicação de cobalto e molibdênio na cultura do amendoim. Bragantia, 1995, 54, 2, 361-370.

Campo, R. J.; Araújo, R. S.; Hungria, M. Molybdenum-enriched soybean seeds enhance $\mathrm{N}$ accumulation, seed yield, and seed protein content in Brazil. Field Crops Research, 2009, 110, 3, 219-224. 
Conkerton, A. J.; Ross, L. F.; Daigle, D. J.; Kvien, C. S.; McCombs, D. S. The effect of drought stress on peanut seed composition. II. Oil, protein and minerals. Oleagineux, 1989, 44, 12, 593-602.

Crusciol, C. A. C.; Lazarini, E.; Golfeto, A. R.; Sá, M. E. de. Produtividade e componentes da produção do amendoim da seca em razão da época de semeadura e da aplicação de cálcio. Pesquisa Agropecuária Brasileira, 2000, 35, 8, 1549-1558.

Crusciol, C. A. C.; Ferrari Neto, J.; Mui, T. S.; Franzluebbers, A. J.; Costa, C. H. M. da; Castro, G. S. A.; Ribeiro, L. C.; Costa, N. R. Rhizobial inoculation and molybdenum fertilization in peanut crops grown in a no tillage system after 20 years of pasture. Revista Brasileira de Ciência do Solo, 2019, 43, 1-19.

Du, Y.; Liao, X.; Hung, Z.; He, J.; Yuan, C. Studies on characteristics of $B$ and Mo absorption accumulation and distribution of $B$ and Mo combined use on Peanut. Soil and Environmental Sciences, 1999, 04, 12-16.

Gillier, P.; Silvestre, P. El cacahuete o maní. Barcelona: Blume, 1970. 281 p.

Godoy, I. J. de; Bolonhezi, D.; Michelotto, M. D.; Finoto, E. L.; Kasai, F. S.; Freitas, R. S. de. Amendoim. In: Aguiar, A. T. da E.; Gonçalves, C.; Paterniani, M. E. A. G. Z.; Tucci, M. L. S.; Castro, C. E. F. de. Instruções Agrícolas para as principais culturas econômicas. Campinas: Instituto Agronômico, 2014, 22-27.

Kasai, F. S.; Paulo, E. D.; Godoy, I. J. de; Nagai, V. Influência da época de semeadura no crescimento, produtividade e outros fatores de produção em cultivares de amendoim na região da alta paulista. Bragantia, 1999, 58, 1, 95-107.

Malavolta, E.; Vitti, G. C.; Oliveira, S. A. Avaliação do estado nutricional das plantas: princípios e aplicações. Piracicaba: Potafos, 1997. $319 p$.

Nakagawa, J.; Rosolem, C. A.; Almeida, R. M. Efeito da maturação e dos métodos de secagem na qualidade de sementes de amendoim. Revista Brasileira de Sementes, 1986, 8, 3, 83-98.
Nogueira, R. J. M. C.; Távora, F. J. A. F. Ecofisiologia do amendoim (Arachis hipogaea L.). In: Santos, R. C. dos (Ed.). $O$ agronegócio do amendoim no Brasil. Campina Grande: Embrapa, 2005. 71-122.

Quaggio, J. A.; Godoy, I. J. Amendoim. In: Raij, B. van, Cantarella, H., Quaggio, J. A.; Furlani, A. M. C. (Eds.) Recomendações de adubação e calagem para o Estado de São Paulo. Campinas: Instituto Agronômico/ Fundação IAC, 1997. p. 285.

Raij, B. van; Andrade, J.C.; Cantarella, H.; Quaggio, J. A. Análise química para avaliação da fertilidade de solos tropicais. Campinas: Instituto Agronômico, 2001. $285 p$.

Rao, R. C. N.; Singh, S.; Sivakumar, M. V. K.; Srivastava, K. L.; Williams, J. H. Effect of water deficit at different growth phases of peanut. I. Yield responses. Agronomy Journal, 1985, 77, 5, 782-786.

Ross, L. F.; Kvien, C. S. The effect of drought stress on peanut seed composition. I. Soluble carbohydrates, tartaric acid and phenolics. Oleagineux, 1989, 44, 6, 295-301.

Silva, M. P. da; Sá, M. E. de; Berti, C. L. F.; Santos, P. C. dos; Abrantes, F. L.; Souza, L. C. D. de. Doses de cálcio e molibdênio via sementes e calcário via solo na produção de sementes de amendoim. Revista Trópica, 2009, 3, 2, 42-52.

Silva, M. P. da; Sá, M. E. de; Abrantes, F. L.; Souza, L. C. D. de. Influência do molibdênio e do cálcio aplicados via semente nas frações protéicas de amendoim cv.IAC 888. Semina: Ciências Agrárias, 2012, 33, 6, 20992108 .

Smith, B.W.Arachis hypogaea. Normal megasporogenesis and syngamy with occasional single fertilization. American Journal of Botany, 1956, 43, 2, 81-89.

USDA, National Resources Conservation Service. Keys to Soil Taxonomy. Soil Survey Center.

Zheng, Y.; Cheng, Q.; Wu, L.; Sun, K.; Wu, Z.; Wang, C. Effects of boron fertilizer and molybdenum fertilizer on growth and development and yield of dryland peanut. Crops, 2011, 05, 53-58. 